\title{
On the Application of the Total Physical Response Approach to Vocabulary Teaching in the Third Grade of Primary School \\ Ying Qiu
}

School of Foreign Languages, Northwestern Polytechnical University, Xi'an 710072, China

13201821918@163.com

Key words: Total Physical Response Approach, vocabulary teaching, physical actions

\begin{abstract}
Traditional methods of vocabulary teaching overemphasize forms of vocabulary and grammar instead of meanings (Jie Jingyuan, 1997), which contributes that students lose their interest in learning English. Total Physical Response (TPR), put forward by James Asher, is a language teaching approach. This paper explores the application of TPR approach to vocabulary teaching in the third grade of primary school by carrying out a teaching experiment. The results reveal that the experiment group has a better command of the vocabulary spelling than that of the control group and physical actions can stimulate students' interest in learning.
\end{abstract}

\section{INTRODUCTION}

Vocabulary is considered as the brick of English language (Wu fei, 2012). But traditional approaches of vocabulary teaching lay stress on grammar instead of meanings, what methods teachers should use to teach English effectively turns into a question. Total Physical Response (TPR), put forward by James Asher in 1960s, holds that teaching languages with actions (Asher, 2012). Some procedures must be followed. First, teachers give instruction and do physical actins accordingly. Students just need to listen and observe (Wang Yiming, 2004:49). Second, teachers give instructions and do physical actions, and students do as what teachers have done. Third, teachers give instructions without doing anything, and students do physical actions according to teachers' instructions. Last, some students give instructions and other students complete physical actions alone or with the help of teachers (Hu Tieqiu, 2000:33).

Children are more likely to remember words which associate with a fun game, an interesting picture, a song, or an absurd situation. Thus TPR covers many teaching modes, including drawing, music, game, role play, competition, etc. This paper will conduct a teaching experiment to investigate the application of TPR approach to vocabulary teaching.

\section{METHODOLOGY AND RESEARCH QUESTIONS}

A teaching experiment was carried out in order to find out the value of the application of the TPR approach to vocabulary teaching in the third grade of primary school. The target students were in their third grade in Dong Da Central Primary school in Xi'an, Shaanxi, China. Forty students from two classes were selected. Each class accounted for twenty. They were local and about eight years old. It was the first time that they started learning English. They were divided into two groups, including the experiment group and the control group. The experiment group used the TPR approach. The control group adopted the traditional teaching methods.

The textbook used was the English Textbook of the Third Grade published by the People's Education Press. Twenty verbs and verb phrases totally were chosen. The experiment lasted four weeks from March9, 2015 to April4, 2015. The teacher gave four lessons each week. Every class lasted forty minutes.

Pretest and posttest were embraced. The purpose of pretest is to learn the students' English ability. The format of the posttest was the same as the pretest. The only difference lies in the test contents. There were ten questions in the test. Each question was worth ten points. Ten questions were divided into two types. Five 
questions belong to dictation. For another five questions, students were asked to write out the meanings of vocabulary. The results of the tests were analyzed by the software SPSS20.0, in the form of the T-test.

This research attempts to answer the following questions:

(1) How to apply the TPR approach to the vocabulary teaching of the third grade of primary schools?

(2) Does the experiment group have a better command of vocabulary than the control group?

\section{DATA ANALYSIS AND DISCUSSION}

\subsection{The Results of Data Analysis of the Pretest}

\subsubsection{The Independent Sample T-Test of the Pretest of Both Groups}

In order to know whether the English ability of the two groups is at the same level, the pretest was conducted. The specific data analysis is as follows:

T-Test

\begin{tabular}{|l|l|l|l|l|l|}
\hline \multicolumn{5}{|c|}{ Group Statistic } \\
\hline & Groups & $\mathrm{N}$ & Mean & Std. Deviation & Std. Error Mean \\
\hline $\begin{array}{l}\text { Pretest } \\
\text { Scores }\end{array}$ & EG & 20 & 93.0000 & 5.71241 & 1.27733 \\
\cline { 2 - 6 } & CG & 20 & 92.5000 & 6.38666 & 1.42810 \\
\hline
\end{tabular}

(Notes: $\mathrm{EG}=$ Experimental Group $\quad \mathrm{CG}=$ Control Group)

As this chart shows, the mean score of the two groups are different. Obviously the mean score of the EG is 93 which is higher than the CG which is about 92. It indicates little difference between the mean scores of EG and CG.

Independent-Sample T-test of the Pretest between EG \& CG

Independent Sample Test

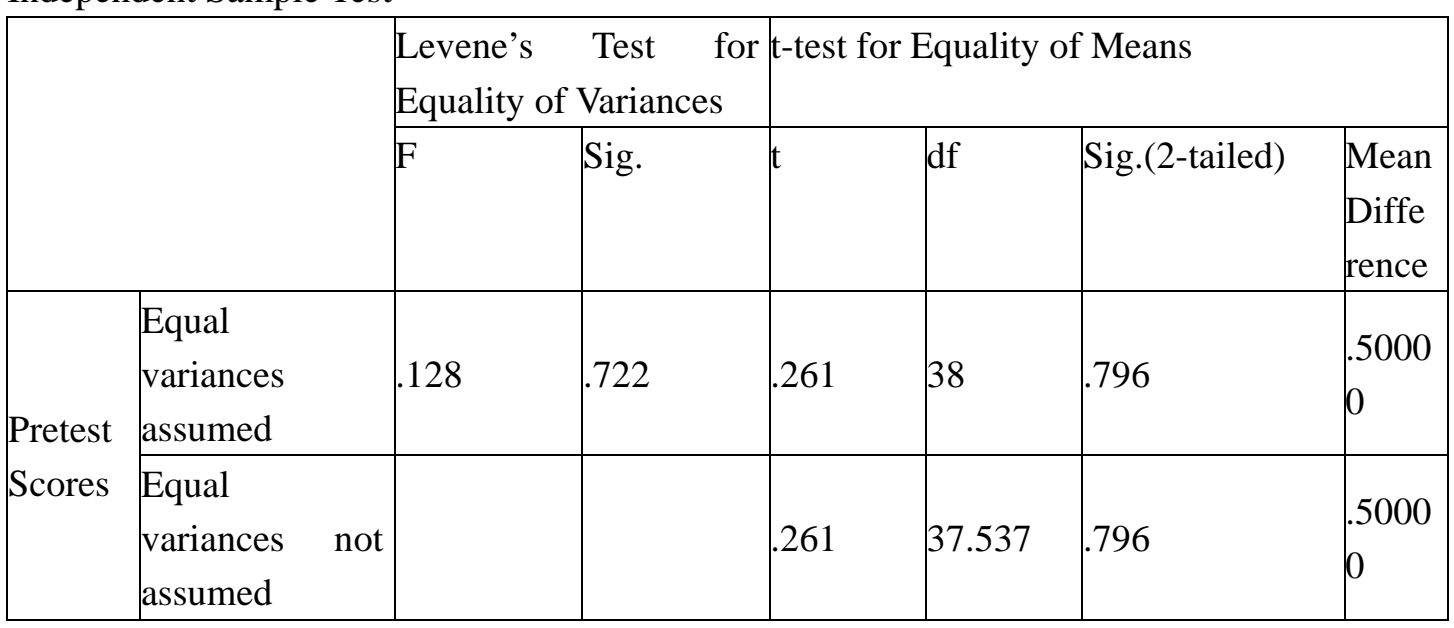

Independent Sample Test

\begin{tabular}{|l|l|l|l|l|}
\hline \multicolumn{2}{|c|}{} & \multicolumn{4}{|l|}{ t-test for Equality of Means } \\
\cline { 3 - 6 } & $\begin{array}{l}\text { Std. Error } \\
\text { Difference }\end{array}$ & $\begin{array}{l}\text { 95\% Confidence Interval of } \\
\text { the Difference }\end{array}$ \\
\cline { 3 - 5 } & & Lower & Upper \\
\hline $\begin{array}{l}\text { Pretest } \\
\text { Scores }\end{array}$ & $\begin{array}{l}\text { Equal variances assumed } \\
\text { Equal variances not }\end{array}$ & 1.91600 & -3.37874 & 4.37874 \\
\hline
\end{tabular}

As can be seen from the Independent-Sample T-Test analysis of the data, the statistical significance (sig.) of Levene's Test for Equality of Variances is $0.722(>0.05)$ and the Sig(2-tailed) is $0.796(>0.05)$, which means that there is no difference concerning the knowledge of vocabulary between two groups. 


\subsection{The Results of Data Analysis of the posttest}

\subsubsection{The Independent Sample T-Test of the Posttest of Both Groups}

The purpose of the posttest is to check the value of the application of TPR approach after the experiment.

T-Test

\begin{tabular}{|l|l|l|l|l|l|}
\hline \multicolumn{5}{|c|}{ Group Statistic } \\
\hline & Groups & $\mathrm{N}$ & Mean & Std. Deviation & Std. Error Mean \\
\hline Pretest & EG & 20 & 100.0000 & .00000 & .00000 \\
\cline { 2 - 6 } Scores & CG & 20 & 96.7500 & 7.30447 & 1.63333 \\
\hline
\end{tabular}

(Notes: EG= Experimental Group $\quad \mathrm{CG}=$ Control Group)

This chart shows that the mean scores of the two groups are different. The mean score of the EG is 100 and is higher than the CG which is about 97, which finds a little difference between the mean scores of the EG and the CG.

Independent Sample Test

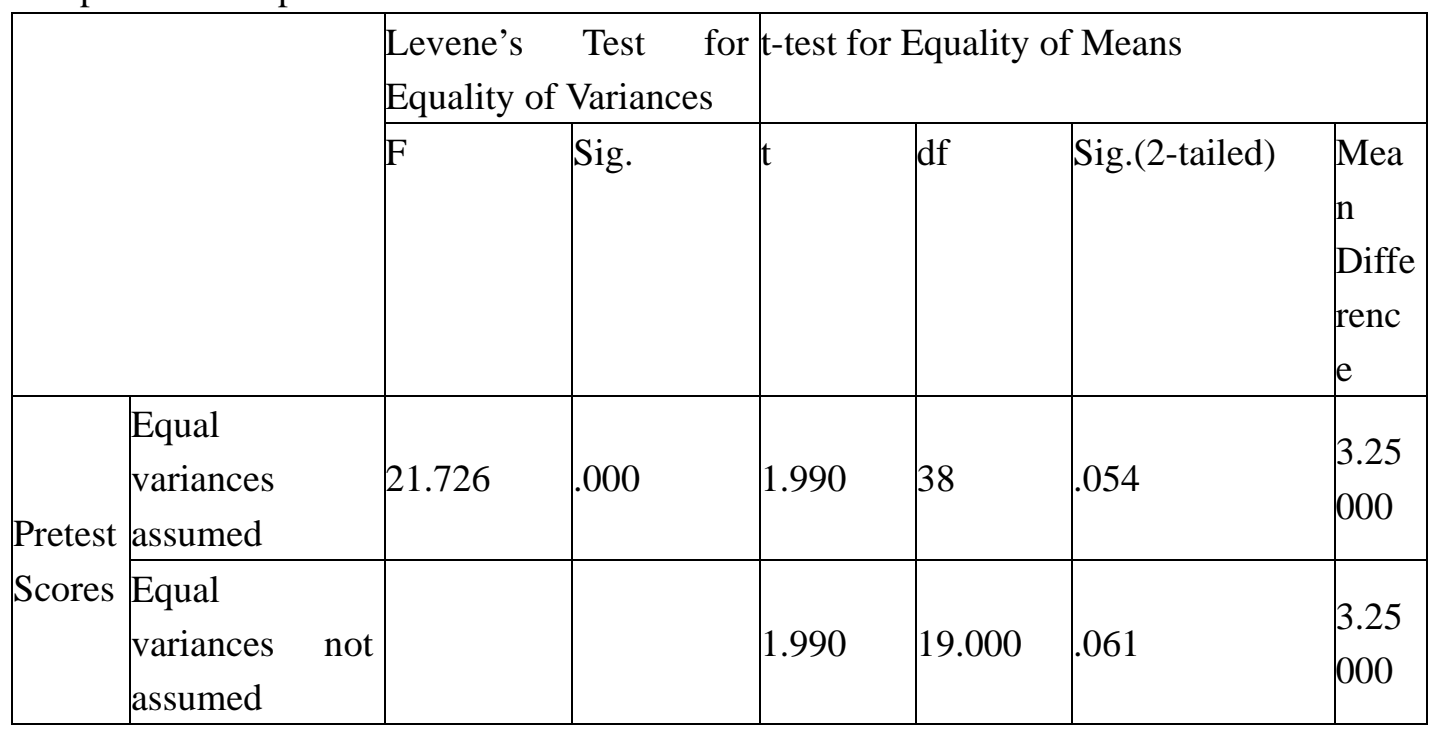

Independent Sample Test

\begin{tabular}{|l|l|l|l|l|}
\hline \multicolumn{2}{|c|}{} & \multicolumn{4}{|l|}{ t-test for Equality of Means } \\
\cline { 3 - 5 } \multicolumn{2}{|l|}{$\begin{array}{l}\text { Std. Error } \\
\text { Difference }\end{array}$} & $\begin{array}{l}\text { 95\% Confidence Interval of } \\
\text { the Difference }\end{array}$ \\
\cline { 3 - 5 } & & Lower & Upper \\
\hline $\begin{array}{l}\text { Pretest } \\
\text { Scores }\end{array}$ & \begin{tabular}{l} 
Equal variances assumed \\
\cline { 3 - 5 }
\end{tabular} & 1.63333 & -.05650 & 6.55650 \\
\hline
\end{tabular}

According to the Independent-Sample T-Test analysis of the data, there is a significant difference concerning the vocabulary learning between two groups. The vocabulary learning of the EG had improved and was better than the CG, because the statistical significance (sig.) of Levene's Test for Equality of Variances is $0.000(<.0 .05)$.

\subsection{Discussion}

The results show that there is no distinction in English level between two groups. But after teaching experiment, there is a significant difference between them. The mean score of the experiment group is higher than the control group. The experiment group has a better command of the vocabulary spelling than that of the control group. So the TPR approach can help students with their vocabulary learning. 


\section{CONCLUSION}

The TPR approach emphasizes learning with physical actions (Asher,1969). It can create a more relaxing atmosphere in class. The students learn the language under less pressure. The results show that the experiment group has a good command of vocabulary spelling than the control group. This answers the second research question and indicates that the TPR approach has several advantages compared with the traditional teaching method. The results also imply the answer to the first research question. Children are active and playful and they cannot pay full attention to study. Thus how to stimulate their interest becomes a question. The TPR approach encourages students to learn English by actions, so words taught in class are mainly verbs or verb phrases by combining the pictures of words and physical actions. During the teaching process, the students were asked to imitate actions until they could do actions by themselves. Gradually the students turned to be more active in class.

\section{Reference}

[1] Xie Jingyuan (1997), The Probability of Application of TPR in China, Journal of Hei Longjiang Education College, Vol. 4, 82-83

[2] Wu Fei (2012) , On the Application of TPR to Elementary English Teaching, Northern Literature, Vol.7, pp183

[3] Asher, James J. "What is TPR?" in TPR-World. Retrieved on 2012-05-29

[4] Wang Yiming (2004), On the Application of the TPR to English Teaching in Primary School, Journal of Foreign Languages of Shandong Normal University, Vol. 4, 48-49

[5] Hu Tieqiu (2000), TPR—A New Way to Teach, Chinese Sci-tech Translation, Vol.1,54-55

[6] "The Total Physical Response Approach to Second Language Learning" by James J. Asher. The Modern Language Journal, Vol. 53, No. 1 (Jan., 1969), pp. 3 